\title{
MAKNA RITUAL MULUd DALAM MEWUJUDKAN popularitas goloK ciomas
}

\section{THE RITUAL MEANING OF MULUD IN CIOMAS MACHETE POPULARITY}

\author{
Risa Nopianti \\ Balai Pelestarian Nilai Budaya Bandung \\ Jalan Cinambo No.136 Ujungberung - Bandung \\ e-mail : risanopianti@gmail.com
}

Naskah Diterima: 9 Januari 2017 Naskah Direvisi: 15 Februari $2017 \quad$ Naskah Disetujui: 23 Februari 2017

\begin{abstract}
Abstrak
Penelitian difokuskan kepada ritual Mulud golok Ciomas yang diselenggarakan setiap tanggal 12 Mulud. Ritual ini berfungsi sebagai ajang silaturahmi para pemilik golok Ciomas, hingga golok Ciomas akhirnya dapat dikenal dan mengharumkan nama Ciomas. Prosesi ritual ngoles/ngulas pada golok Ciomas yang telah jadi, dan tempa pada besi bakal pembuatan golok Ciomas, merupakan filosofi bertemunya antara guru dan murid yang hanya terjadi satu tahun sekali yaitu pada bulan Mulud. Pertanyaannya kemudian bagaimana ritual tersebut diselenggarakan hingga menarik minat masyarakat, kemudian faktor-faktor apa saja yang ada dalam sistem ritual Mulud, yang menjadikan golok Ciomas begitu populer di mata masyarakat. Penelitian ini dilakukan dengan menggunakan metode kualitatif dengan pendekatan etnografis. Adapun data diperoleh melalui proses wawancara, pengamatan, dan studi pustaka. Akhirnya penelitian ini menemukan bahwa kepopuleran golok Ciomas dicapai karena adanya usaha dan kerja sama yang erat antara beberapa stakeholder yang ada di lingkaran golok Ciomas yaitu pande golok, pemimpin ritual, dan pemegang pusaka godam Si Denok.
\end{abstract}

Kata kunci: golok, Ciomas, ritual Mulud.

\section{Abstract}

The study focuses on the Mulud ritual of Ciomas machete held annually on 12 of Mulud. This ritual serves as a gathering place of Ciomas machete owners, and then Ciomas machete finally can be popular and becomes the icon of the Ciomas. Ritual procession of ngoles or ngulas of finished Ciomas machete, and wrought iron of Ciomas machete designate, become a meeting philosophy between teachers and students that only happens once in a year, i.e. in Mulud. The question is then how the ritual is held to attract people, and then what factors are presented in the system of Mulud ritual which makes Ciomas machete, becomes so popular. This research is conducted by applying a qualitative method with ethnographic approach. The data is obtained through interviews, observation, and literature study. Finally, it is found that the Ciomas machete achieved popularity for the efforts and close cooperation between multiple stakeholders in the circle of Ciomas. It is Pande, a leader of the ritual, and the holder of the heritage sledgehammer, Si Denok.

Keywords: machete, Ciomas, Mulud ritual.

\section{A. PENDAHULUAN}

Pada hakikatnya manusia adalah makhluk individu, sosial, dan religius. Sebagai individu manusia dianugerahi akal untuk berfikir dan nafsu untuk menyalurkan keinginan biologisnya.
Sedangkan sebagai makhluk sosial manusia secara nyata diciptakan untuk hidup berkelompok, serta saling melengkapi antara satu dan yang lainnya. Kemudian yang terakhir adalah manusia sebagai makhluk religius, yang berarti 
bahwa dengan akal yang dimilikinya berfikir mengenai sesuatu yang besar yang terkait dengan keyakinan akan hal-hal yang bersifat gaib dan sakral. Hingga kemudian timbul suatu kepercayaan dan keyakinan.

Otak, fikiran dan daya nalar yang dimiliki manusia merupakan anugerah yang paling sempurna yang diberikan Tuhan. Melalui kesempurnaannya itu manusia bisa berpikir, bertindak, berusaha, dan bisa menentukan mana yang benar dan baik. Begitu pula mengenai kepercayaan dan keyakinannya terhadap Tuhan, yang diperolehnya melalui proses berfikir.

Evolusi berfikir manusia mengenai keberadaan Tuhan dan agama telah ada semenjak manusia hadir di muka bumi atau dalam arti lain, lahirnya agama dan kepercayaan umurnya setua manusia itu sendiri. Hingga beberapa ahli telah menelaah berbagai teori mengenai hal tersebut, dimulai dari teori yang paling sederhana hingga yang paling kompleks.

Agama sebagai bentuk keyakinan manusia terhadap sesuatu yang bersifat supernatural memiliki fungsi serta berdampak cukup luas bagi manusia dalam kehidupannya sehari-hari. Agama memiliki nilai-nilai yang dijadikan petunjuk dan pegangan hidup bagi kehidupan manusia sebagai orang per orang maupun dalam hubungannya dengan kehidupan bermasyarakat. Selain itu agama juga memiliki fungsi sosial yaitu menciptakan suatu ikatan bersama baik antara anggotaanggota beberapa masyarakat maupun dalam kewajiban-kewajiban sosial yang mempersatukan mereka ${ }^{1}$.

Setiap kelompok masyarakat memiliki kebudayaannya masing-masing. Kebudayaan yang hidup pada suatu masyarakat, pada dasarnya merupakan gambaran dari pola pikir, tingkah laku, dan nilai yang dianut oleh masyarakat yang bersangkutan. Dari sudut pandang ini, agama di satu sisi memberikan kontribusi terhadap nilai-nilai budaya yang ada,

\footnotetext{
${ }^{1}$ Mahakarya, 2012
}

sehingga agama pun berjalan atau bahkan akomodatif dengan nilai-nilai budaya yang sedang dianut masyarakat bersangkutan (Ghazali, 2011: 31).

Dalam hal tersebut dikatakan bahwa agama memiliki fungsi sebagai integratif factor atau fungsi menyatukan, yaitu pengaruh yang bersifat positif atau pengaruh yang menyatukan. Atau dengan kata lain berfungsi untuk memelihara dan menumbuhkan sikap solidaritas di antara sesama individu atau kelompok. Solidaritas merupakan ekspresi dari tingkah laku beragama (Ghazali, 2011: 33).

Sebagai wujud nyata dari solidaritas beragama adalah ritus atau ritual. Ritual juga menggambarkan sikap penghormatan masyarakat terhadap sesuatu yang berkuasa dengan persembahan-persembahan di dalamnya. Salah satu ritual penghormatan kepada leluhur adalah ritual Mulud golok Ciomas, yang dimaksudkan sebagai penghormatan kepada leluhur Ciomas, yaitu Ki Cengkuk yang telah berjasa menciptakan sebuah golok yang sangat istimewa.

Golok tersebut kemudian dikenal dengan nama golok Ciomas. Popularitas golok Ciomas muncul karena keistimewaannya, dimulai dari proses pembuatannya yang dipenuhi oleh ritualritual dan persyaratan-persyaratan tertentu, alat dan bahan yang khusus harus berasal dari Ciomas, serta keberadaan pande atau pembuat golok yang hanya mampu dilakukan oleh satu keluarga saja. Fenomena golok Ciomas menarik untuk ditelusuri lebih jauh utamanya unsur-unsur mistis, magis dan faktor-faktor lain yang melekat daripadanya, sehingga golok Ciomas menjadi populer di masyarakat.

Beberapa penelitian mengenai golok Ciomas pernah ditulis oleh para peneliti, khususnya mereka yang konsen terhadap kebudayaan Banten. Beberapa di antaranya adalah tulisan-tulisan Ayatullah Humaeni mengenai Ritual, Kepercayaan Lokal, dan Identitas Budaya Masyarakat Ciomas Banten. Dalam tulisannya ini 
Humaeni menganalisa bahwa ritual-ritual yang dilakukan oleh masyarakat Ciomas terkait dengan keberadaan golok Ciomas di dalamnya, memiliki fungsi untuk menghapus pandangan negatif yang melekat pada citra jawara yang banyak terdapat di Ciomas, selain itu ritual-ritual tersebut juga memiliki fungsi sosial yaitu untuk merekatkan solidaritas sosial di antara sesama masyarakat. Ayatullah Humaeni juga menulis mengenai Makna Kultural Mitos dalam Budaya Masyarakat Banten. Pada penelitian ini Humaeni menemukan bahwa keberadaan mitos pada masyarakat Banten, sedikit banyak, berpengaruh terhadap kehidupan sosial keagamaan masyarakat Banten. Mitos, dalam beberapa hal, juga memiliki fungsi dan peran yang cukup signifikan bagi masyarakat Banten seperti untuk mengukuhkan sesuatu, menjaga identitas kultural dan solidaritas masyarakat, serta mempertahankan prestise dan status sosial.

Mengacu pada rujukan beberapa tulisan di atas, penulis tertarik pada popularitas yang ada pada golok Ciomas. Hal tersebut dirasa penulis belum ada yang meneliti sebelumnya maka dengan ini penulis ingin mengetahui bagaimana, oleh siapa saja, serta faktor-faktor apa saja yang menopang popularitas golok Ciomas, sehingga mampu menjadi ikon Banten sekaligus kebanggaan masyarakat Banten, sekaligus juga melihat bagaimana, oleh siapa, dan seperti apa Ritual Mulud dilaksanakan.

\section{B. METODE PENELITIAN}

Berdasarkan proses dan hasil yang dilakukan, penelitian ini merupakan jenis penelitian kualitatif ${ }^{2}$. Sebagaimana yang diutarakan Sugiyono (2005: 21) bahwa penelitian kualitatif adalah "Metode

\footnotetext{
2 Jenis penelitian kualitatif meledak ketika Lexy Moleong mengeluarkan buku mengenai penelitian kualitatif pada tahun 1998, sekalipun dikatakan sebagai penelitian kualitatif, tetapi sebetulnya hanya bersifat deskriptif (Arikunto, 2013: 21).
}

deskriptif yang digunakan untuk menggambarkan atau menganalisis suatu hasil penelitian tetapi tidak digunakan untuk membuat kesimpulan yang lebih luas."

Sebuah penelitian kualitatif lebih menekankan proses daripada hasil. Sehingga rangkaian proses yang ditempuh haruslah sesuai dan sistematis. Sebagaimana yang disampaikan Moleong (2000: 4-8) bahwa ciri penelitian kualitatif di antaranya; lingkungan alamiah sebagai sumber data, manusia sebagai alat, metode kulitatif, analisis data secara induktif, grounded theory, deskriptif, ada batas yang ditentukan fokus, lebih mementingkan proses daripada hasil, ada kriteria khusus untuk keabsahan data, desain bersifat sementara, hasil penelitian dirundingkan dan disepakati bersama.

Penelitian kualitatif dimulai dengan mengumpulkan data-data primer dan sekunder, yang diperoleh melalui teknik wawancara, pengamatan, dan pencermatan. Kemudian data diolah dan dianalisa secara induktif, sehingga dapat dipaparkan secara deskriptif dengan tujuan utamanya menjawab pertanyaan penelitian yang telah diajukan.

\section{Pendekatan Teoritis}

\section{a. Religi, Ritual, Mistis, dan Magis.}

Agama atau para ahli lainnya menyebut religi merupakan sesuatu yang bersifat given yang telah ada pada diri manusia semenjak lahir. Menurut Durkheim agama adalah sesuatu yang bersifat sosial, artinya sekalipun agama sudah melekat pada diri individu-individu namun hal tersebut bersifat sosial, artinya pilihan beragama tetap berada dalam kerangka sosial ((Pals, 2012: 164).

Menurut Koentjaraningrat (2005: 203-204) terdapat lima unsur dasar yang membentuk religi yaitu: emosi keagamaan, sistem kepercayaan, sistem ritus dan upacara keagamaan, kelompok keagamaan, serta alat-alat fisik yang digunakan dalam ritus dan upacara. 
Ritus adalah alat manusia untuk melakukan perubahan. Bisa juga dikatakan sebagai tindakan simbolis agama, atau ritual merupakan "agama dalam tindakan" (Ghazali, 2011: 50). Menurut Susane Langer dalam (Ghazali, 2011: 52) ritual memperlihatkan tatanan atas simbolsimbol yang diobyekkan. Simbol-simbol ini mengungkapkan perilaku dan perasaan serta bentuk disposisi pribadi dan para pemujanya. Menurutnya ritual dapat dibedakan menjadi empat macam:

- Tindakan magi, yang dikaitkan dengan penggunaan bahan-bahan yang bekerja karena daya magis.

- Tindakan religius, kultus leluhur, juga bekerja dengan cara yang pertama.

- Ritual konstitutif, yang mengubah hubungan sosial dengan merujuk pengertian-pengertian mistis.

- Ritual faktitif yang meningkatkan produktifitas atau kekuatan, atau pemurnian dan perlindungan, atau dengan kata lain meningkatkan kesejahteraan materi suatu kelompok.

Sedangkan menurut Durkheim (2011: 433-557), ritual terbagi kedalam lima bentuk yaitu: pemujaan negatif dan fungsifungsinya; pemujaan positif elemenelemen pengurbanan, pemujaan positif ritus mimetik dan prinsip kausalitas, pemujaan positif ritus representatif dan kommemoratif (peringatan) ${ }^{3}$; dan ritusritus piakular.

Ritual dan upacara keagamaan memiliki empat aspek di antaranya: tempat upacara keagamaan dilakukan; saat-saat upacara keagamaan dijalankan, bendabenda dan alat-alat upacara; orang-orang yang melakukan dan memimpin upacara (Koentjaraningrat, 2009: 296).

Kelima unsur dasar religi tersebut saling mempengaruhi satu sama lain, membentuk sebuah struktur dimana emosi

\footnotetext{
3 Menurut Durkheim ritus representatif dan kommemoratif bertujuan untuk membangkitkan ide dan perasaan, menggabungkan masa sekarang dan masa lalu, menggabungkan yang individu dan yang kolektif.
}

keagamaan menjadi pusat dari berjalannya sistem religi di masyarakat. Emosi keagamaan merupakan sebuah getaran jiwa yang menggerakkan seseorang atau sekelompok orang untuk bersikap religius. Dengan demikian segala hal yang bersangkutan dengan perilaku keagamaan menjadi keramat atau sakral (Koentjarangirat, 2005: 202).

Konsep sakral dalam pemikiran Durkheim merupakan bagian dari agama atau religi. Durkheim mengatakan bahwa agama adalah sistem kepercayaan dengan perilaku-perilaku yang utuh dan selalu dikaitkan dengan yang sakral. Tujuan yang sakral adalah menyatukan komunitas moral atau emosi keagamaan dalam sebuah wadah komunitas atau kelompok keagamaan (Pals, 2012: 145).

Dalam teori-teori religi juga terdapat konsep mistis dan magis yang keduanya mengandung pengertian yang hampir sama karena bersifat rahasia, dan gelap. Menurut Harun Nasution, intisari mistisme, termasuk di dalamnya sufisme, yaitu kesadaran akan adanya komunikasi dan dialog antara roh manusia dengan Tuhan dengan mengasingkan diri dan berkontemplasi (Nasution, 2014: 43).

Sedangkan menurut Frazer (Pals, 2012: 146) magis serupa dengan agama hanya dengan cara yang berbeda. Agama dan magis sama-sama berusaha menjelaskan cara kerja alam agar dapat dikuasai oleh manusia. Lain halnya Durkheim yang mendefinisikan magis sebagai hal-hal yang sifatnya pribadi dan hampir tidak ada hubungannya dengan yang sakral atau agama tadi ${ }^{4}$.

\section{b. Ritual sebagai Fungsi Sosial}

Konsep mengenai fungsi sosial ini dilontarkan pertama kali oleh Radcliff-

\footnotetext{
${ }^{4}$ Durkheim mencontohka tidakan magis seperti dukun mengobati pasiennya yang sakit, hal tersebut bersifat personal karena praktek magis hanya dapat dilakukan oleh orang-orang tertentu saja, sedangkan agama bersifat sosial. Seorang agamawan pastilah memiliki pengikut (jemaat), tetapi seorang dukun tidak.
} 
Brown. Menurutnya istilah fungsi sosial dapat digunakan untuk menyatakan efek dari suatu keyakinan, adat, atau pranata, kepada solidaritas sosial dalam masyarakat (Koentjaraningrat, 1987: 176).

Upacara religi atau upacara keagamaan yang dilakukan masyarakat memiliki fungsi sosial. Rumusan mengenai hal tersebut dipaparkan oleh RadcliffBrown pada bab pertama bukunya The Andaman Islanders (1922) sebagai berikut:

(1) agar suatu masyarakat dapat hidup langsung, maka harus ada suatu sentimen dalam jiwa para warganya yang merangsang mereka untuk berperilaku sesuai dengan kebutuhan masyarakat; (2) tiap unsur dalam sistem sosial dan tiap gejala atau benda yang dengan demikian mempunyai efek solidaritas masyarakat, menjadi pokok orientasi dari sentimen tersebut; (3) sentimen itu ditimbulkan dalam pikiran individu warga masyarakat sebagai pengaruh hidup masyarakatnya; (4) adat-istiadat upacara adalah wahana dengan apa sentimen-sentimen itu dapat diekspresikan secara kolektif dan berulang-ulang pada saat-saat tertentu; (5) ekspresi kolektif sentimen memelihara intensitas sentimen itu dalam jiwa masyarakat, dan bertujuan meneruskannya kepada generasi berikutnya (Koentjaraningrat, 1987: 176).

\section{c. Makna Simbolik}

Menurut Spredley (1997) makna menyampaikan pengalaman sebagian besar umat manusia di masyarakat. Untuk mengungkapkan sebuah makna diperlukan adanya kata, kalimat dan apa yang dibutuhkan untuk berkomunikasi. (Sobur, 2013:255-256)

Sebuah makna juga dapat diungkap melalui simbol. Pada umumnya kata-kata juga merupakan sebuah simbol, begitu pula sebuah objek, suara, sosok, dan sebagaimya dapat dikategorikan sebagai sebuah simbol (Danesi, 2010:44).
Sebuah teori untuk mengungkap makna yang ada dibalik setiap peristiwa adalah interaksionisme simbolik. Salah satu ahlinya adalah Herbert Blumer. Interaksionisme simbolik Blumer merujuk pada suatu karakter interaksi khusus yang berlangsung antar-manusia. Aktor tidak semata-mata bereaksi terhadap tindakan yang lain tetapi dia menafsirkan dan mendefinisikan setiap tindakan orang lain. Terdapat tiga prinsip utama dalam interaksionisme simbolik, yaitu tentang pemaknaan (meaning), bahasa (language), dan pikiran (thought). Premis ini nantinya mengantarkan kepada konsep "diri" seseorang dan sosialisasinya kepada "komunitas" yang lebih besar yaitu masyarakat ${ }^{5}$.

\section{d. Struktur Sosial}

Kata struktur menunjuk pada aktivitas membangun sesuatu dan menghasilkan produk yaitu mengembangkan suatu tindakan. Kemudian konsep ini diperluas pada hubungan bagian-bagian yang membentuk organ. Sosiologi menggunakan konsep ini yang menunjuk pada masyarakat sebagai organisme secara keseluruhan yang tereduksi pada individu dan berbagai tindakan mereka (Scott, 2011-248).

Menurut para ahli terdahulu di antaranya Koentjaraningrat mengatakan bahwa struktur sosial adalah kerangka yang dapat mengaitkan berbagai unsur dalam masyarakat. Sedangkan Soeleman B. Taneko menjelaskan bahwa struktur sosial adalah keseluruhan jalinan antara unsur-unsur sosial yang pokok yakni kaidah-kaidah sosial, lembaga-lembaga sosial, kelompok-kelompok sosial serta lapisan-lapisan sosial (Setiadi dan Kolip, 2011: 39).

Dalam struktur sosial terdapat komponen-komponen pokok yang saling berkaitan serta saling mempengaruhi satu

\footnotetext{
${ }^{5}$ Dikutip dari

http://yoonhyewon.blogspot.co.id/2013/08/teor i-interaksionisme-simbolik-h-blumer.html tanggal 30 Maret 2017.
} 
dengan yang lainnya, kelima komponen utama yang mendukung terbentuk atau berjalannya sebuah struktur sosial tersebut adalah status dan peranan, lembaga sosial, pelapisan sosial, kelompok-kelompok sosial, dan dinamika sosial.

Struktur sosial dengan komponenkomponen yang membentuknya merupakan bagian dari kebudayaan. Sedangkan kebudayaan terdiri dari unsurunsur yang saling terstruktur, sebagaimana halnya pada struktur sosial. Sebagaimana yang dirumuskan oleh Strauss mengenai konsep segi tiga kuliner $^{6}$. Pemikiran Strauss mengenai kebudayaan yang diibaratkan makanan membentuk sebuah segi tiga yang saling berhubungan satu sama lainnya. Tiga unsur tersebut memiliki wujud dan fungsi yang berbeda, namun ketiganya saling mendukung membentuk sebuah kebudayaan. Unsur-unsur alami, semi-alami, dan tidak alami menjadi pokok utama pembentuk segi tiga kuliner Strauss.

\section{Kerangka Pemikiran}

Ritual merupakan bagian dari religi yang dalam lingkup yang lebih besar termasuk kedalam salah satu unsur kebudayaan. Terlepas dari apakah ritual tersebut diperuntukkan bagi yang sakral atau hanya sebatas praktik magis yang penuh dengan aroma mistis, pada dasarnya ritual-ritual tersebut memiliki fungsi sosial. Begitu pula halnya dengan ritual muludan di Kecamatan Ciomas, yang menjadikan golok Ciomas sebagai elemen utama pelaksanaan ritual. Fungsi sosial pada ritual Mulud sangat kentara terlihat manakala masyarakat Ciomas merasakan bahwa ritual Mulud sudah menjadi sebuah kebutuhan bersama, sebagai akibat dari adanya sentimen-sentimen dari warga masyarakatnya terhadap keberadaan golok Ciomas.

Pada dasarnya sentimen-sentimen masyarakat yang terlembagakan dalam wujud ritual muludan, tidak cukup untuk

\footnotetext{
${ }^{6}$ Lihat Koentjaraningrat, 1987 mengenai konsep segi tiga kuliner yang dirumuskan Claude Levi-Strauss.
}

tetap melanggengkan tradisi tersebut, bahkan apabila harus diturunkan secara turun temurun sekalipun, sebab ritual muludan membutuhkan lembaga-lembaga sosial yang menopangnya. Dalam proses ritual Mulud, terdapat beberapa struktur sosial yang saling mempengaruhi dan menopang terselenggaranya ritual Mulud tersebut. Struktur-struktur yang ada di masyarakat Ciomas seperti pemegang pusaka golok $\mathrm{Si}$ Rebo dan godam $\mathrm{Si}$ Denok, pande pembuat golok Ciomas, serta ulama pemimpin ritual serta para tokoh masyarakat lain yang memiliki peranan yang cukup besar dalam penyeleggaraan ritual, bekerja keras dan setiap kali menjelang dan pada saat ritual Mulud diselenggarakan.

Keberadaan mereka sangat penting sehingga ritual Mulud dapat terselenggara dengan baik, dan terlegitimasi oleh masyarakat sebagai sebuah ritual wajib yang harus selalu ada untuk melestarikan tradisi dan warisan budaya leluhur masyarakat Ciomas.

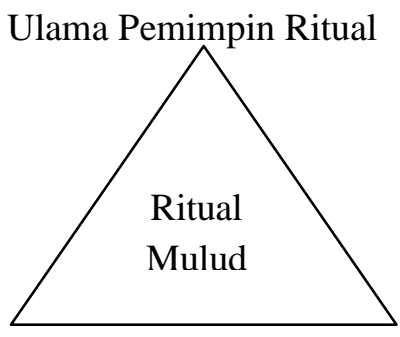

Pemegang Pusaka Pande Golok

\section{Hipotesa}

Popularitas golok Ciomas yang dikenal masyarakat secara luas saat ini, tidak terlepas dari adanya ritual Mulud yang rutin digelar sebagai bentuk silaturahmi antara golok dan godam yang diibaratkan sebagai murid dan guru. Sedangkan ritual Mulud tetap lestari semata karena adanya struktur masyarakat yang mendukung tetap terselenggaranya kegiatan tersebut. Mereka adalah ahli waris pemegang godam, pandai golok, serta ulama pemimpin ritual. Yang ketiganya diibaratkan membentuk sebuah segi tiga 
penopang unsur kebudayaan dalam hal ini ritual Mulud golok Ciomas di Kecamatan Ciomas.

\section{HASIL DAN BAHASAN}

Kemajemukan ragam budaya sejumlah suku bangsa di Indonesia dapat diketahui dari berbagai budaya yang ada, baik itu budaya lisan, tulisan, budaya bendawi dan nonbendawi. Menurut Koenaningrat (2005: 12), melalui bagan kerangka kebudayaan yang diciptakannya, kebudayaan dapat dikelompokkan menjadi tujuh unsur besar yaitu; sistem pengetahuan, sistem teknologi dan peralatan hidup, sistem ekonomi dan mata pencaharian, organisasi sosial dan sistem kekerabatan, religi dan sistem kepercayaan, kesenian, dan bahasa.

Sistem teknologi adalah jumlah keseluruhan dari teknik-teknik yang dimiliki oleh anggota suatu masyarakat, yaitu keseluruhan dari cara bertindak dan berbuat dalam hubungannya dengan pengumpulan bahan-bahan mentah dari lingkungannya dan memprosesnya menjadi alat kerja, alat untuk menyimpan, makanan, pakaian, perumahan, alat-alat transportasi, dan kebutuhan lain yang berupa materil (Harsojo, 1977: 223) Adapun yang dimaksud dengan sistem teknologi tradisional adalah peralatan serta cara-cara mempergunakan peralatan tersebut dalam kehidupan sehari-hari yang sifatnya masih sederhana dan diwariskan secara turun-temurun. Sistem teknologi tradisional dapat berupa sistem teknologi peralatan hidup, sistem arsitektur tradisional, sistem pembuatan kuliner, dan lain-lain.

Sedangkan sistem teknologi peralatan hidup, merujuk pada jenis perkakas atau senjata yang biasa digunakan oleh manusia dalam menunjang kehidupannya. Senjata tradisional memiliki beberapa fungsi yang sangat penting dalam menunjang kehidupan manusia, selain sebagai alat untuk mempertahankan diri, juga dapat memiliki fungsi estetis yang dapat disimpan sebagai koleksi.
Beberapa jenis senjata tradisional sudah banyak dikenal oleh masyarakat, di antaranya, rencong dari Aceh, badik dari suku Bugis di Makassar, mandau dari suku Dayak di Kalimantan, keris dari Jawa, kujang dari Sunda, celurit dari Madura, dan golok dari Banten.

Menurut Kamus Besar Bahasa Indonesia (2013: 457), golok adalah pisau besar terbuat dari besi atau baja yang digunakan untuk membelah atau memotong. Menurut ukurannya dibedakan antara golok dan parang. Golok ukurannya sejenis parang atau pedang yang berukuran pendek. Sedangkan parang sendiri berukuran lebih panjang daripada golok. Sedangkan pengertian golok dalam Kamus Umum Basa Sunda (2006:24), golok adalah bedog yaitu pakarang parati kudak kadek atau alat yang berfungsi untuk memotong.

Golok (bedog) umumnya memiliki bilah dengan panjang lebih kurang $30 \mathrm{~cm}$ sampai dengan $40 \mathrm{~cm}$, namun adapula bilah golok yang berukuran pendek atau kurang dari $30 \mathrm{~cm}$. Golok (bedog) Sunda yang memiliki panjang bilah lebih dari 40 $\mathrm{cm}$ disebut kolewang atau gobang ${ }^{7}$. Sedangkan di wilayah DKI Jakarta dan Banten, umumnya digunakan sebagai senjata pamor bagi para jawara silat, atau dapat pula disimpan sebagai koleksi karena nilai atau harganya yang cukup tinggi serta kandungan mistis di dalamnya.

\section{Golok Ciomas Sebuah Identitas}

Golok Ciomas merupakan salah satu jenis senjata tradisional yang pembuatannya juga masih dilakukan dengan teknologi tradisional. Wilayah persebaran golok di daerah Banten hampir merata di setiap kota kabupaten, namun lebih khusus berada di Serang, Pandeglang, Lebak, dan Rangkasbitung. Wilayah Kabupaten Serang terpusat di Kecamatan Ciomas dan Kecamatan Petir,

\footnotetext{
${ }^{7}$ Dikutip dari

http://www.zhaloedistrosunda.com/2014/12/be

dog-sunda-atau-golok.html. tanggal 30

September 2016
} 
sedangkan di Kabupaten Lebak golok lebih dikenal di wilayah adat Kanekes (Baduy).

Sebagaimana

dijelaskan

sebelumnya, secara umum kata golok dalam Kamus Umum Bahasa Indonesia, diartikan sebagai benda sejenis parang, atau sejenis pedang yang berukuran lebih pendek. Jawara Banten sangat identik dengan kepemilikan golok, hal ini ditengarai karena fungsi utamanya tadi yaitu sebagai alat untuk membela diri. Sebagai seorang jawara yang memiliki kemampuan bela diri mumpuni, tentunya golok merupakan atribut pelengkap, tandangnya seorang jawara.

Begitu pula halnya bagi seorang jawara debus, yang saat ini lebih banyak bergeser pada tatar seni budaya dan tradisi. Seorang jawara atau ahli debus pastilah memiliki golok, karena golok merupakan alat utama pertunjukan seni debus, disamping paku dan godam yang biasa digunakan. Ketajaman sebilah golok biasanya selalu diujikan pada anggota badan para jawara, dalam setiap pertunjukan seni debus. Kemampuan kanuragan maupun trik-trik unik dilakukan untuk menangkal ketajaman golok Banten, yang dikenal sangat tajam.

Namun ternyata konsep ini semakin hari bergeser pada bentuknya yang lain. Kepemilikan golok saat ini tidak hanya identik dengan keberadaan seorang jawara, siapapun dapat memiliki golok tanpa harus memiliki kemampuan bela diri. Pergeseran ini disebabkan golok telah menjadi benda koleksi yang memiliki nilai estetis.

Golok Ciomas, yang sebagian besar merupakan jenis golok pamor, sangat banyak diminati oleh masyarakat umum, sekalipun harganya cukup mahal. Harga yang dibanderol demikian disebabkan golok Ciomas tidak dapat diproduksi besar-besaran karena khusus dibuat pada bulan Mulud saja, sehingga jumlahnya terbatas.

Sebagai sebuah ikon, golok Ciomas juga sering digunakan sebagai cenderamata kepada para pejabat atau tamu-tamu istimewa yang berkunjung ke Ciomas.
Bahkan saat ini pandai golok Ciomas Bapak Sidik dan keluarganya memproduksi miniatur golok Ciomas. Miniatur golok tersebut dibuat pada bulanbulan lain selain bulan Mulud. Hal tersebut dilakukan untuk mengisi waktu luang serta menambah penghasilan mereka, karena apabila hanya mengandalkan pembuatan golok yang hanya boleh dilakukan di bulan Mulud, tidak akan mampu mencukupi kebutuhan hidup sehari-hari.

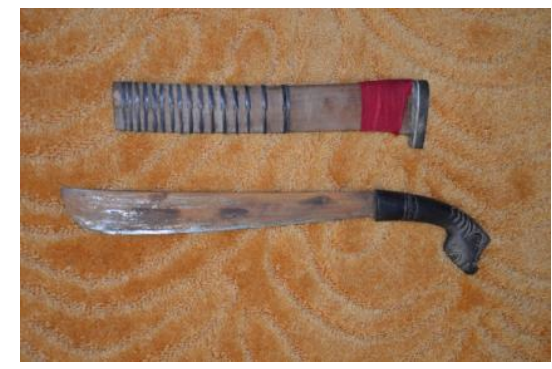

Gambar 1. Golok Ciomas

Sumber: BPNB Jabar, 2015.

Keistimewaan golok Ciomas sudah tidak diragukan lagi, banyak yang mengatakan bahwa pamor golok Ciomas berimbas pada pemiliknya. Barangsiapa memiliki golok Ciomas, sudah jelas mereka akan dihormati dan ditakuti. Golok Ciomas juga konon katanya mampu melerai perselisihan hanya dengan disandang saja tanpa harus dikeluarkan dari sarangkanya. Golok Ciomas dikenal memiliki racun yang sangat mematikan, sehingga apabila tergores sedikit saja luka yang ditimbulkan akan sangat buruk. Begitu pula apabila ditebaskan pada pepohonan, racunnya dapat dengan cepat mematikan tumbuhan tersebut.

\section{Ragam Jenis Golok Sulangkar Ciomas}

Dari sekian banyak jenis golok Banten yang ada, salah satu yang paling terkenal adalah golok Ciomas. Ketenaran golok Ciomas terjadi karena golok Ciomas memiliki kharisma tersendiri sebagai sebuah golok. Umumnya golok Ciomas digunakan sebagai golok pamor atau golok koleksi. Jarang sekali dipergunakan sebagai senjata atau bahkan perkakas. Hal 
ini disebabkan harganya yang relatif mahal bagi sebagian orang, serta sugesti mistis yang ada di dalamnya. Sehingga golok Ciomas banyak diminati masyarakat khususnya mereka yang ingin memiliki benda langka dan memiliki nilai artistik tinggi.

Lebih khusus lagi salah satu jenis golok Ciomas yang memiliki nilai dan tingkat artistik tingggi adalah golok sulangkar. Dinamakan golok sulangkar karena diambil dari salah satu jenis besi yang digunakan, yaitu besi sulangkar. Besi sulangkar itu merupakan besi yang diambil dari injakan, undakan, foot step delman yang sudah tua. Besi injakan delman itulah yang disebut besi sulangkar. Besi pelat sulangkar ini dapat juga diperoleh dari bekas pelat mobil bekas, kikir bekas, bahkan ranjang besi bekas. Syaratnya jenis besi sulangkar yang dipergunakan harus asli berasal dari jenis pelat hitam yang sudah tua dan pernah dipergunakan oleh orang-orang zaman dulu atau bekas pakai. Karena menurut mitos yang beredar di Ciomas, konon besi-besi kuno dipercayai mengandung unsur mistis yang kuat, sehingga ketika dijadikan golok, aura mistisnya akan ada di dalam golok tersebut.

Untuk mengetahui seluk beluk Ciomas, golok Ciomas serta ritual Mulud golok Ciomas, perlu mengetahui ragam jenis golok sulangkar yang ada saat ini di Ciomas. Setidaknya terdapat empat jenis golok yang ada di Ciomas, yaitu candung, mamancungan, kembang kacang, salam nunggal dan sedikit jenis malapah gedang dan bedul mungkuk. Masing-masing memiliki ciri tersendiri. Hanya yang paling banyak diproduksi adalah jenis candung.

Gagang golok sulangkar Ciomas juga bervariasi sesuai bentuknya. Terdapat lima jenis gagang golok di antaranya jengkol sahulu, wawayangan, mamanukan, babalimbingan, dan jebug sapasi. (Solihin dan Supriatna, 2011: 63-73).

Adapun untuk gagang golok sulangkar Ciomas biasanya menggunakan jenis kayu jawar berwarna hitam. Tekstur kayu jawar lunak namun keras sehingga mudah diukir dan dibentuk, serta bersifat anti rayap sehingga cocok untuk dibuat gagang golok. Selain kata jawar juga identik dengan kata jawara. Sehingga golok sulangkar Ciomas terkenal sebagai golok para jawara. Sedangkan sarangkannya biasa terbuat dari kayu aren.

Untuk membuat sebuah golok Ciomas asli diperlukan persyaratan khusus yang harus dipenuhi pembuatnya, di antaranya (Solihin dan Supriatna, 2011: 49-60):

a. Pembuatan golok sulangkar Ciomas hanya dibuat setahun sekali di bulan Mulud (Rabiul Awal). Waktu pembuatan yang paling utama adalah dari tanggal 1-12 Mulud, namun demikian melewati tanggal 12 juga masih diperbolehkan asalkan tidak melewati bulan Mulud. Waktu pembuatan golok pada bulan Mulud sesuai dengan bulan kelahiran Rasulullah SAW pada tanggal 12 Mulud maka dari itu ritual Mulud golok Ciomas pun dilaksanakan bertepatan pada tanggal 12 Mulud.

b. Untuk menjadi sebuah golok Ciomas asli terlebih dahulu harus ditempa atau dioles oleh godam Si Denok pada saat ritual Mulud. Setelah itu boleh dilanjutkan dengan godam biasa milik pande. Penempaan bahan baku besi/baja bakalan golok ini dilakukan oleh penjaga pusaka golok Si Denok saat ini, yaitu Bapak Duhari. Sedangkan untuk golok Ciomas yang sudah jadi, para pemilik golok disarankan untuk melakukan ritual pengolesan golok oleh godam Si Denok. Maksud dari ritual ini adalah sebagai ajang silaturahmi antara golok yang dianalogikan sebagai murid dengan godam Si Denok sebagai guru.

c. Bahan baku utama pembuatan golok sulangkar Ciomas terdiri dari besi inti dan besi tambahan. Yang dimaksud dengan besi inti adalah besi tua yang diperoleh dari daerah setempat, khususnya daerah Pondok Kaharu dan Bojong Honje. Kualitas golok akan 
lebih bagus apabila besi inti tersebut diperoleh melalui penggalian khusus berdasarkan petunjuk dari orang yang mampu menangkap ilafat tersebut.

d. Golok sulangkar Ciomas bukan merupakan golok biasa, maka dari awal pencarian bahan baku besi, kemudian ditempa oleh godam Si Denok, hingga selesai berbentuk golok, keberadaan sebuah golok Ciomas selalu diiringi dengan ritual, bacaan dan mantramantra khusus. Khususnya pada tahap akhir untuk "mengisi" golok yang sudah jadi, dilakukan pembacaan mantra melalui golok, supaya golok yang dibuat dapat memberi manfaat positif bagi pemiliknya.

e. Dibuat di Ciomas, sesuai dengan sejarahnya dimana pada masa lalu $\mathrm{Ki}$ Cengkuk pernah tinggal dan membuat golok pertama kali di Ciomas maka hingga saat ini yang dinamakan golok Ciomas harus dibuat di Ciomas.

f. Air dari Babakan Ciomas, di daerah Ciomas terdapat tujuh mata air yang memancarkan air jernih langsung dari perut bumi. Nama beberapa sumber mata air tersebut cukup unik yaitu Cibunut, Cibikang, dan Cilalaki. Semua sumber air tersebut sangat berlimbah airnya, dan tidak pernah kering walupun musim kemarau. Air yang diambil dari ketujuh sumber mata air ini selain digunakan untuk prosesi ritual Mulud golok Ciomas, juga digunakan oleh pande sebagai air untuk mendinginkan golok yang ditempa. Setelah menempuh sejumlah persyaratan yang harus dilalui oleh sebuah calon golok sulangkar Ciomas maka tahap selanjutnya adalah proses penempaan hingga sebuah bahan baku besi calon golok dapat dibentuk menjadi sebuah golok yang sempurna.

Untuk membuat sebuah golok Ciomas, terlebih bahan baku besi inti dan campuran yang telah berbentuk lempengan disatukan oleh capit kemudian dibakar. Lempengan yang telah menjadi bara kemudian ditempa hingga menjadi sebuah kesatuan. Kemudian dibakar lagi dan ditempa lagi begitu seterusnya hingga beberapa kali, untuk menghasilkan sebuah bilah golok yang diinginkan.

Selanjutnya setelah golok jadi baru dilakukan finishing atau penghalusan dengan menggunakan kikir dan ampelas. Terlebih dahulu biasanya digunakan kikir listrik untuk meratakan dan membentuk bilah golok. Baru kemudian setelah bilah golok terbentuk dengan permukaan rata tanpa gelombang, bilah golok diampelas untuk menghaluskan detail, baru kemudian diasah oleh batu asahan untuk memperoleh tingkat ketajaman golok yang diinginkan.

Proses selanjutnya adalah memasangkan gagang. Gagang golok yang terbuat dari kayu jawar terlebih dahulu dipotong sesuai ukuran. Rata-rata sebuah gagang golok biasanya berukuran 20x10 $\mathrm{cm}$ tergantung jenis gagang yang diinginkan. Baru kemudian kayu dipahat menggunakan golok untuk mendapatkan bentuk utama. Tahap selanjutnya pembuatan gagang golok, pada tahap ini alat yang digunakan adalah pisau ukir. Gagang golok yang telah terukir rapi sesuai dengan bentuk pesanan yang diinginkan,kemudian diampelas untuk selanjutnya diwarnai.

Sedangkan untuk membuat sarangka, kayu aren dipotong berdasarkan panjang pendeknya ukuran golok yang akan diberi sarangka. Kayu dibelah menjadi dua bagian, bagian dalam kedua belahan kayu tersebut diberi pola golok pasangannya, kemudian dicukil secukupnya supaya ketika golok dimasukkan ukurannya pas. Setelah selesai menggarap bagian dalam sarangka, kedua bilah kayu sarangka disatukan dengan lem pada masing-masing sisinya, sedangkan bagian dalamnya tidak supaya golok tidak terhalang masuk. Baru kemudian setelah sarangka terekatkan dibentuk dan dihaluskan. Tahap akhir adalah pemasangan asesoris seperti sompal, simeut meuting, dan cincin.

\section{Ritual 12 Mulud}

a. Godam Si Denok dan Golok Si Rebo 
Keberadaan pusaka godam $\mathrm{Si}$ Denok dan golok Si Rebo merupakan bagian yang tidak dapat dipisahkan dengan keberadaan golok Ciomas. Golok Ciomas yang ada saat ini dan menjadi kebanggaan masyarakat Ciomas, ada karena sejarah godam Si Denok dan golok Si Rebo yang melegenda hingga saat ini.

Godam Si Denok merupakan godam milik $\mathrm{Ki}$ Cengkuk yang biasa digunakan $\mathrm{Ki}$ Cengkuk untuk menempa golok, sedangkan golok Si Rebo merupakan golok pertama $\mathrm{Ki}$ Cengkuk yang dibuat menggunakan tempaan $S i$ Denok. Panjang golok ini mencapai kurang lebih $70 \mathrm{~cm}$. Gagangnya sendiri sudah hilang termakan usia, dan hingga saat ini belum diganti dengan yang baru, namun dibiarkan begitu saja, hanya dibalut oleh kain putih. Sedangkan bilah golok Si Rebo sudah berkarat akibat korosi besi dan tumpul, dengan bagian perut bilah golok sedikit bergerigi karena korosi tadi. Terbuat dari besi dan baja pilihan, kondisi godam Si Denok masih baik hingga saat ini, namun sedikit mengalami lumerisasi pada bagian kepala godam akibat sering digunakan untuk menempa golok.

Kedua pusaka tersebut disimpan dengan sangat baik oleh pemegang pusaka. Disimpan dalam dua buah kotak kayu yang berbeda, dan diberi wewangian. Setiap kali dibuka dan dipergunakan untuk ritual Mulud, kedua pusaka tersebut diberi wewangian lagi. Penanganan dan pemeliharaan terhadap kedua benda pusaka tersebut menandakan bahwa mereka begitu dikeramatkan, sehingga memiliki nilai sakralitas yang tinggi bagi masyarakat para keturunan $\mathrm{Ki}$ Cengkuk khususnya dan masyarakat Ciomas umumnya. Saat ini godam dan golok pusaka warisan $\mathrm{Ki}$ Cengkuk dijaga oleh Ki Duhari.

\section{b. Prosesi Ritual Mulud}

Ritual 12 Mulud merupakan ritual puncak dari keseluruhan rangkaian pembuatan golok Ciomas. Ritual ini diawali dengan puasa dan pembacaan doadoa khusus atau tawasulan sebelum golok dibuat. Sebelum membuat golok, para sesepuh di Ciomas yaitu tokoh-tokoh terkait pembuat golok seperti Kyai Muhaimin, Bapak Oman Solihin, dan lainlain biasanya mengadakan acara tawasulan, yaitu ziarah makam ke makammakamleluhur Ciomas, khususnya ke makam Ki Cengkuk sebagai tokoh utama keberadaan golok sulangkar Ciomas di daerah Ciomas.

Bahan baku golok yang digunakan bukan bahan sembarangan, melainkan berupa besi inti khusus yang harus digali dari dalam tanah yang ada di wilayah Desa Pondok Kahuru dan Bojong Honje. Untuk mendapatkan besi inti tidak mudah mesti melalui riyadhoh yakni melakukan wiridan dan puasa jauh-jauh hari sebelum bulan Mulud. Sedangkan bahan campuran untuk membuat golok Ciomas digunakan sebanyak tujuh campuran dan paling sedikit lima campuran. Adapun air yang digunakan untuk merendam atau menyepuh golok saat pembuatannya nanti pun harus berasal tujuh sampai sembilan mata air yang ada di daerah Ciomas.

Proses ritual muludan dimulai pada saat besi inti mulai ditemukan kemudian digali dan diambil sebagai bahan baku pembuatan golok. Setelah itu dilakukan pengumpulan air yang diambil dari tujuh mata air di daerah Ciomas pada malam hari tanggal 11 Mulud menjelang tanggal 12 Mulud. Keseluruhan proses persiapan ini dilakukan oleh masyarakat Ciomas yang dipimpin oleh ulama setempat.

Pada waktu yang sama juga, godam Si Denok dibawa ke tempat pande. Sebelum Si Denok di bawa ke pande, terlebih dahulu dilakukan tawasul dan tahlil oleh paling sedikit tiga orang, dan salah satunya haruslah keturunan $\mathrm{Ki}$ Cengkuk (Solihin dan Supriatna, 2011: 78).

Puncaknya tanggal 12 Mulud seluruh tamu dan undangan, yaitu mereka pemilik golok Ciomas yang berasal dari berbagai daerah berkumpul di rumah Bapak Duhari sebagai penjaga pusaka 
golok Si Rebo dan godam Si Denok. Pada saat itu seluruh golok dikumpulkan untuk ditempa atau dioles oleh godam Si Denok.

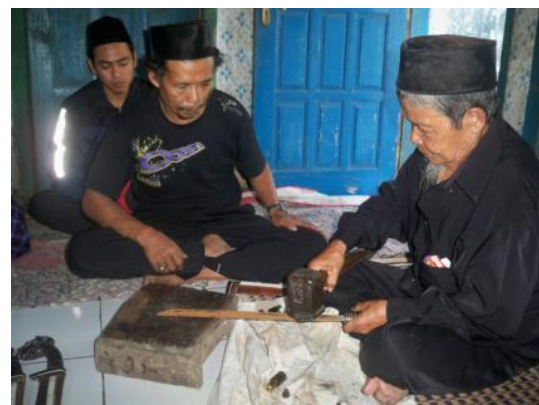

Gambar 2. Ritual Mulud Golok Ciomas Sumber: Oman Solihin.

Supaya sebuah golok atau bakalan golok dapat ditempa oleh Si Denok, ada mahar tersendiri yang harus dibayar oleh pemilik atau pemesan golok. Setiap genjreng (pukulan) pada zaman dahulu diistilahkan sagenjreng saringgit, dua genjreng dua ringgit. Bila saat ini dimaharkan sekitar lima puluh ribu rupiah/genjreng. Tiap satu tempaan disertai bacaan tertentu yang hanya dilafalkan oleh Bapak Duhari. Adapun untuk mengoles golok yang sudah dibuat sebelumnya, maharnya hanya persepuluhnya.

Tanggal 12 Mulud dipilih sebagai waktu pelaksanaan ritual Mulud, sebab masyarakat mempercayai bahwa tanggal tersebut merupakan tanggal baik karena bertepatan dengan hari kelahiran Nabi Muhammad SAW. Selain itu ada juga yang mengatakan bahwa angka 12 menunjukkan angka 12 yaitu jumlah Rukun Islam, Rukun Iman, dan Ihsan. Angka 12 juga sesuai dengan jumlah huruf La Illaha Illallah. Angka 12 juga mengandung arti, syarat pemegang golok yakni enam syarat fisik, dan enam syarat batin $^{8}$ (Solihin dan Supriatna, 2011: 80).

\footnotetext{
${ }^{8} 6$ syarat fisik yaitu bersuci, salat, zakat, puasa, berhasil, dan fii sabilillah. 6 syarat batin yaitu tawakal, tafwidz, taubat, khauf, ridho, ikhlas, dan zuhud.
}

\section{Struktur Sosial Golok Ciomas}

Dalam konsep sosiologi dan antropologi kita mengenal adanya struktur sosial dalam tubuh sebuah masyarakat. Struktur sosial ini mengacu pada organisme masyarakat yang terdiri dari beberapa komponen sosial dalam membentuk sebuah tindakan sosial.

Begitu pula halnya pada masyarakat Ciomas, terdapat beberapa komponen sosial dalam masyarakat yang menopang sebuah tindakan sosial yang bernama ritual Mulud. Dalam menjaga tradisi golok Ciomas sebagai sebuah warisan budaya leluhur masyarakat Ciomas, terdapat setidaknya tiga struktur yang saling berkaitan. Pertama adalah pande golok, pemegang pusaka godam $\mathrm{Si}$ Denok, dan pemimpin ritual Mulud. Ketiga struktur ini tidak dapat berdiri sendirisendiri, melainkan saling berkaitan antara satu dengan yang lainnya.

Mereka adalah Bapak Duhari sebagai pemegang pusaka godam Si Denok dan golok Si Rebo, Bapak Muhaimin ulama yang biasa memimpin ritual Mulud, dan Bapak Sidik pande golok Ciomas.

Ki Duhari merupakan keturunan ke-7 pemegang pusaka Ki Cingkuk tersebut. Adapun sebelum Ki Duhari, sebelumnya dipegang oleh Ki Jamsari yang merupakan ayah dari Ki Duhari. Berikut adalah silsilah pemegang pusaka godam Si Denok dan golok Si Rebo Ki Cengkuk : 1). Ki Buyut Cengkuk, 2). Ki Buyut Boma, 3). Ki Buyut Mala, 4). Ki Buyut Sakiman, 5). Ki Buyut Sandara, 6). Ki Jamsari, 7). Ki Duhari

Pemegang psaka Si Denok dan Si Rebo saat ini adalah Bapak Duhari. Bapak Duhari merupakan keturunan Ki Cengkuk yang diwariskan pusaka Si Denok dan $\mathrm{Si}$ Rebo dari Bapak Jamsari yang tidak lain adalah ayahnya sendiri. Sehari-hari Duhari adalah seorang petani. Ia tinggal di Kampung Cihujan, Desa Lebak, Ciomas. Lalu bagaimana hingga akhirnya godam $S i$ Denok berada di tangan Duhari, bukan keturunan Ki Cengkuk yang lain. Menurut penuturan Duhari, bahwa hanya dirinyalah 
yang dianggap mampu memegang pusaka tersebut, sebab keturunan Ki Cengkuk lain tidak kuat. Umumnya mereka akan jatuh sakit pada saat memegang pusaka tersebut. Hal ini berarti mereka tidak cocok menjaga pusaka. Terbukti dengan dipindahkannya pusaka tersebut, penyakit mereka seketika sembuh. Tetapi hal tersebut tidak terjadi pada Duhari, sehingga Duhari dianggap mampu menjaga dan merawat godam $\mathrm{Si}$ Denok.

Ritual Mulud syarat dengan ritual yang cukup panjang, sehingga dibutuhkan seseorang yang dapat memimpin ritual tersebut, beliau adalah Ki Muhaimin. Ki Muhaimin merupakan salah satu keturunan Ki Cengkuk. Dengan kemampuan ilmu agamanya yang mumpuni sebagai ulama dan tokoh masyarakat Ciomas, $\mathrm{Ki}$ Muhaimin didaulat menjadi pemimpin ritual Mulud golok Ciomas. Ki Muhaimin banyak berperan dalam ritual Mulud, beliau juga mengetahui banyak tentang ritual dan maknanya (Solihin dan Supriyadi, 2011: 40).

Ki Muhaimin, mulai menekuni tradisi ritual Mulud sejak tahun 80-an, bersamaan dengan pembukaan pesantren yang dipimpinnya, Sanabil Huda. Beliau merasa terpanggil untuk melestarikan sejarah golok Ciomas semata supaya dapat memberikan manfaat pada masyarakat banyak (Solihin dan Supriyadi, 2011: 37).

Ki Muahimin bertugas dari awal, yaitu sejak pertama kali mendapatkan ilafat atau petunjuk mencari lokasi besi ini di daerah Ciomas hingga sebuah golok Ciomas selesai dibuat oleh pande. Pada hari $\mathrm{H}$ tanggal 12 Mulud Ki Muhaimin juga bertugas memimpin do'a dan shalawat pembuka ritual untuk selanjutnya didaulatkan kepada Bapak Duhari yang bertugas mengoles dan menempa golok dengan godam Si Denok.

Tokoh lain yang juga memiliki peran dan andil cukup besar dalam mengharumkan nama golok Ciomas ke pelosok Nusantara adalah Sidik Santani. Beliau adalah satu-satunya pande golok yang ada di Ciomas. Menurutnya hanya keturunan Ki Cengkuk lah yang dapat membuat golok Ciomas, sebab Ki Cengkuk lah yang pertama kali membuat golok Ciomas dengan kekuatan tangannya. Sehingga sampai saat ini, untuk membuat sebuah golok Ciomas tidak dapat sembarangan, melainkan harus melalui ritual dan tahapan tertentu.

Keahlian Bapak Sidik membuat golok diperolehnya secara turun temurun. Dari Ki Buyut Cengkuk, ilmu membuat golok Ciomas berturut-turut diturunkan kepada Ki Boma, dari Ki Boma kepada Ki Mala, dari Ki Mala ke Ki Sakiman, dari Ki Sakiman ke Ki Sandara, dari Ki Sandara ke Ki Mad Sipa, dari Ki Mad Sipa ke Ki Kardian, dari Ki Kardian ke Ki Santani, dari Ki Santani baru ke Bapak Sidik ${ }^{9}$. Saat ini Bapak Sidik juga tengah meregenerasi kemampuannya membuat golok kepada anak-anak dan kerabatnya.

Di belakang rumah Bapak Sidik yang terletak di Kampung Sibopong Girang, Desa Citaman, Kecamatan Ciomas, terdapat sebuah tempat pande sederhana yang dijadikan tempat untuk membuat dan menempa golok Ciomas. Sehari-hari tempat pande ini sepi dari kegiatan pembuatan golok, namun apabila bulan Mulud tiba, kegiatan di pande ini hampir tidak pernah berhenti karena banyaknya pesanan golok yang harus diselesaikan Sidik.

Yang menarik dari tempat pande ini adalah sebuah alat yang dinamakan $u b u b^{10}$, alat ini sudah ada sejak lama, konon katanya sudah digunakan oleh 12 turunan

\footnotetext{
${ }^{9}$ Diakses dari

http://indonesiana.merahputih.com/budaya/201 6/03/28/aneh-hanya-keturunan-ki-buyutcengkuk-yang-bisa-membuat-golokciomas/39688/ tanggal 10 November 2016. Pukul 09.35 wib.

${ }^{10}$ Ubub merupakan alat yang digunakan untuk membuat angin. Terbuat dari kayu nangka setinggi $1,5 \mathrm{~m}$. Alat ini sangat diperlukan untuk mempertahankan bara api, cara kerjanya sama seperti pompa angin digerakan oleh kedua tangan secara bergantian. Alat ini terbuat dari kayu nangka dengan tinggi $1,5 \mathrm{~m}$
} 
pande terhitung Bapa Sidik sebagai pande terakhir yang masih ada. Apabila diambil rata-rata usia pembuat Golok Ciomas ini selama 50 tahun maka usia $u b u b$ saat ini diperkirakan sudah mencapai 600 tahun (Solihin dan Supriyadi, 2011: 37). Usia yang sudah cukup tua seiring keberadaan golok Ciomas.

Untuk membuat sebuah golok, biasanya Bapak Sidik melakukan ritual khusus untuk meminta izin kepada pemilik gaib dimana besi keramat bekas dapat diambil ${ }^{11}$. Apabila pemilik gaib menyetujuinya golok dapat dibuat, tetapi apabila tidak maka Bapak Sidik akan menyampaikannya kepada pemesannya. Sebagai solusinya Sidik akan mengambil besi keramat di daerah lain yang disetujui pemilik gaib. Hal tersebut harus dilakukan Sidik sebagai wujud tata krama kepada para makhluk gaib penjaga golok Ciomas.

\section{Struktur Sosial dalam Ritual Mulud}

Sebagaimana yang diutarakan oleh Durkheim bahwa agama merupakan sesuatu yang bersifat sosial, artinya sekalipun agama sudah melekat pada diri individu-individu namun hal tersebut bersifat sosial, artinya pilihan beragama tetap berada dalam kerangka sosial. Seseorang berhak untuk memilih agama dan kepercayaannya masing-masing sesuai dengan apa yang diyakininya benar. Intervensi terhadap seseorang untuk menganut agama tertentu merupakan sebuah pelanggaran hak azasi manusia, yang sudah dengan jelas termaktub dalam hukum negara kita.

Berbeda dengan agama, religi mencakup hal yang lebih luas tidak terbatas pada percaya atau tidaknya akan keberadaan Tuhan, tetapi lebih kepada yang gaib, yang dianggap memiliki kekuatan besar dan berpengaruh terhadap kehidupan manusia. Religi dalam konteks

11 Bisanya besi-besi bekas tersebut diperoleh didaerah Pondok Kahiru, Bojong Honje, Ciomas, Rampones, dan Cileos. Lokasi yang terakhir disebut sebagai lokasi yang sudah langka besi keramat. ini dianut oleh sebagian dari masyarakat kita, khususnya bagi mereka yang masih hidup dalam kebersahajaan, dimana yang gaib menjadi begitu penting dalam kehidupan mereka. Durkheim menyebutnya Yang Sakral.

Religi sebagai perwujudan penghormatan kepada Yang Sakral memiliki lima pilar penting di dalammnya, sebagaimana yang diuraikan Koentjaraningrat yaitu emosi keagamaan, sistem kepercayaan, sistem ritus dan upacara keagamaan, kelompok keagamaan, serta alat-alat fisik yang digunakan dalam ritus dan upacara. Emosi keagamaan lahir secara alamiah dalam diri setiap manusia. Kesamaan persepsi terhadap emosi keagamaan yang dimiliki oleh individuindividu kemudian dipersatukan dalam sebuah wadah yang dinamakan komunitas keagamaan. Komunitas atau kelompok keagamaan ini kemudian menciptakan sistemnya tersendiri dalam memaknai dan melaksanakan ritualnya. Wujud konkrit dari keberadaan komunitas religi ini adalah pelaksanaan ritual-ritual yang merupakan hal yang penting dari keseluruhan sistem religi, menurut Ghazali ritual merupakan tindakan simbolis agama. Secara keseluruhan emosi keagamaan inilah yang menjadi nafas utama sistem religi.

Dalam hubungannya dengan golok Ciomas, emosi keagamaan yang tercermin dalam sebuah ritual Mulud golok Ciomas semakin mantap kedudukannya secara sosial dalam masyarakat, karena didukung dengan adanya sentimen dalam jiwa para warganya. Sentimen ini bersifat umum, namun kehadirannya dirasakan oleh jiwajiwa para individu masyarakat Ciomas yang dipengaruhi oleh masyarakat, sehingga sentimen tersebut merangsang mereka untuk berperilaku sesuai dengan kebutuhan masyarakat. Kebutuhan masyarakat Ciomas tentunya adalah adanya pengakuan secara masal bahwa mereka memiliki dan mewarisi golok dengan jenis terbaik yang prosesnya sangat istimewa dan langka. Hal tersebut merupakan refleksi dari adanya 
kebanggaan terhadap warisan budaya mereka.

Sebagaimana dalam sebuah sistem religi yang menjadikan sistem ritus dan upacara sebagai media untuk mempererat emosi keagamaan, dalam sentimen juga adat-istiadat dan upacara dapat diekspresikan secara kolektif dan berulangulang. Hal inilah yang kemudian memperkuat sentimen yang diturunkan dari generasi ke generasi. Kondisi tersebut diimplementasi dalam ritual Mulud golok Ciomas. Ritual sebagai bagian dari religi merupakan wadah atau sarana bagi masyarakat pendukungnya untuk menyalurkan sentimen-sentimen. Sentimen akan kebanggaan masyarakat terhadap golok Ciomas sebagai warisan budayanya terlanggengkan dengan dilaksanakannya ritual Mulud golok Ciomas.

Namun ternyata sistem ritual ini tidak dengan sendirinya terlaksana hanya karena adanya sentimen positif dari masyarakat pendukungnya, melainkan harus digerakkan oleh seperangkat struktur sosial yang ada di dalamnya. Struktur sosial inilah yang kemudian memegang peranan penting terlaksananya sebuah sistem ritual. Begitu pula halnya dalam penyelenggaraan ritual Mulud golok Ciomas, ritual ini pada dasarnya tidak dapat terlaksana hanya sebatas sentimen dan emosi sosial saja tanpa adanya penggerak. Penggerak dalam hal ini adalah ketiga unsur struktur sosial penyangga, penjaga dan pelestari golok Ciomas dan ritual Mulud golok Ciomas yaitu pande golok, pemimpin ritual, dan penjaga pusaka golok $\mathrm{Si}$ Rebo dan godam $\mathrm{Si}$ Denok.

Ritual Mulud golok Ciomas merupakan sebuah simbol yang dimaknai sebagai sebuah hal yang sakral bagi penganutnya. Simbol-simbol kesakralan ritual ditandai dari mulai pencarian lokasi bahan baku pembuatan golok, pengambilan air dari tujuh mata air, hingga pengolesan golok dengan godam Si Denok. Ritual Mulud yang ditujukan sebagai media penghormatan dan syukur terhadap leluhur, dilakukan melalui sejumlah mekanisme ritual yang bersifat magis dan mistis, hal ini ditujukan sebagai bentuk komunikasi dua arah antara manusia dengan roh-roh gaib.

Dalam memaknai interaksi antara pemimpin ritual Mulud dengan leluhur yang bersifat mistis tadi, diperlukan adanya komunikasi-komunikasi yang bersifat sugestif terhadap masyarakat, yang memperlihatkan bahwa apa yang dilakukan oleh pemimpin ritual tersebut benar adanya. Sehingga masyarakat mampu mendefinisikan bahwa pada ritual Mulud, kharisma yang ada dalam golok Ciomas dipercaya dapat menguasai kekuatankekuatan gaib yang ada di alam untuk kepentingan manusia. Hasilnya kemudian banyak dari masyarakat beranggapan bahwa golok Ciomas memiliki aura mistis sehingga pemiliknya tertular aura mistisnya hingga disegani orang.

\section{PENUTUP}

Dari pemaparan teori, fakta, dan data di lapangan dapat diketahui bahwa terdapat pengaruh yang cukup kuat dari makna ritual Mulud golok Ciomas terhadap popularitas golok Ciomas itu sendiri. Faktor-faktor keberadaan struktur sosial yang menopang berlangsungnya ritual Mulud golok Ciomas, serta faktor mistis dan magis yang menyertai jalannya ritual Mulud golok Ciomas, merupakan penyebab melambungnya popularitas golok Ciomas di mata masyarakat umum.

Kepopuleran golok Ciomas pada dasarnya merupakan kerja keras semua pihak termasuk masyarakat Ciomas sebagai pendukungnya. Tinggal bagaimana ritual Mulud golok Ciomas sebagai tradisi masyarakat Banten mesti dilestarikan dan dijaga, demi kepentingan semua orang bukan sekelompok orang yang berkepentingan saja.

\section{DAFTAR SUMBER}

\section{Jurnal}

Humaeni, Ayatullah. "Makna Kultural Mitos dalam Budaya Masyarakat Banten” dalam 
Masyarakat Indonesia Vol. 33 No.3 September-Desember 2012. Hlm. 159180.

Humaeni, Ayatullah. "The Local Tradisional of Magical Practice in Banten Society" dalam El-Harakah Vol.14 No.1 Tahun 2012. Hlm. 69-87.

Humaeni, Ayatullah. "Ritual, Kepercayaan Lokal, dan Identitas Budaya Masyarakat Ciomas Banten" dalam El-Harakah Vol.17 No. 2 Tahun 2015. Hlm. 157-181.

\section{Buku}

Arikunto, Suharsimi. 2013.

Prosedur Penelitian; Suatu Pendekatan Praktik. Jakarta : Rineka Cipta.

Danadibrata. R.A. 2006.

Kamus Basa Sunda. Bandung : Kiblat.

Danesi. Marcel. 2010.

Pesan, Tanda, Dan Makna. Yogyakarta: Jalasutra.

Departemen Pendidikan Nasional. 2013. Kamus Besar Bahasa Indonesia Pusat Bahasa cetakan ke-4. Jakarta : Gramedia.

Durkheim, Emile. 2011.

The Elemtary Forms of The Religious Life. Yogyakarta: IRCiSoD

Harsojo.1977.

Pengantar Antropologi. Jakarta: Bina Cipta.

Koentjaningrat. 1987. Sejarah Teori Antropologi I, Cetakan $\mathrm{Ke}$-2. Jakarta : UI Press.

Koentjaraningrat. 2005.

Pengantar Antropologi. Pokok-Pokok Etnografi II cetakan ke-3. Jakarta: Rineka Cipta.

Koentjaraningrat. 2009.

Pengantar Ilmu Antropologi. cetakan ke-IX edisi revisi. Jakarta: Rineka Cipta.

Moleong, Lexy. 2000 Metode Penelitian Kualitatif cetakan ke11. Bandung : Remaja Rosdakarya.

Nasution, Harun. 2014.

Falsafat dan Mistisme dalam Islam. Cetakan ke-12. Jakarta : Bulan Bintang.

Scott John (Editor).2011.
Sosiologi The Key Consepts. Jakarta: Raja Grafindo Persada.

Sobur, Alex. 2013.

Semiotika Komunikasi. Bandung : Remaja Rosdakarya.

Solihin, Oman dan Akhmad Supriatna. 2011. Golok Ciomas. Hikayat dan Keistimewaannya. Banten : LP3SDMBD dan PGRI Provinsi Banten.

Sugiyono, 2005.

Metode Penelitian Kualitatif. Yogyakarta: Gajah Mada Press.

\section{Internet}

Mahakarya, Reza. 2012. "Agama danpengaruhnya dalam kehidupan individu dan masyarakat" diakses dari https://eunchasiluets.wordpress.com/201 2/05/08/makalah-agama-danpengaruhnya-dalam-kehidupanindividu-dan-masyarakat/ Tanggal 19 Oktober 2016.

Yoon, S. 2013. “Teori Interaksionisme Simbolik H. Blumer" diakses dari http://yoonhyewon.blogspot.co.id/2013/ 08/teori-interaksionisme-simbolik-hblumer.html Tanggal 30 Maret 2017. 2014. "Bedog Sunda Atau

Golok" diakses dari http://www.zhaloedistrosunda.com/2014 /12/bedog-sunda-atau-golok.html. Tanggal 30 September 2016.

.2016. “Aneh Hanya Keturunan Ki Cengkuk yang Bisa Membuat Golok Ciomas" diakses dari http://indonesiana.merahputih.com/buda ya/2016/03/28/aneh-hanya-keturunanki-buyut-cengkuk-yang-bisa-membuatgolok-ciomas/39688/. Tanggal 10 November 2016. 